\title{
MENINGKATKAN KEMAMPUAN BERPIKIR KRITIS DAN KEMANDIRIAN BELAJAR MAHASISWA MELALUI PEMBELAJARAN GENERATIF
}

\section{Fadli}

\begin{abstract}
The research aims at analyzing the quality of students' critical thinking and self-learning abilities by applying generative learning method in the subject of Algebra Structure at Mathematics Education Study Program of STKIP PGRI Lubuk Linggau. The variable of the research was the result of generative learning approach to improve critical thinking and self-learning abilities in the subject of Algebra Structure at Mathematics Education Study Program of STKIP PGRI Lubuk Linggau. The research objects were 23 students of the fifth semester class in Mathematic Education Study Program of STKIP PGRI Lubuk Linggau the year of 2009/2010. Research method applied was quasi experiment, with experiment class treated with generative learning method and without control class. The research result showed that in general, the critical thinking and self-learning abilities of Algebra Structure Subject had the mean of 75.90 (with minimum score of 70) meaning, the critical thinking and self-learning abilities of the students were generally in high level. Whereas the analysis result of variants test was $t$-count $=3.954$ and $t$-table (dk $=22, a=1 \%)=2,508$. It showed that the critical thinking and self-learning abilities of the students with generative learning approach in the subject of Algebra Structure at Mathematics Education Study Program of STKIP PGRI Lubuk Linggau was above the score of 70.
\end{abstract}

Keywords: critical thinking, generative learning, algebra structure

\section{Abstrak}

Tujuan dalam penelitian ini adalah untuk menganalisis kualitas kemampuan berpikir kritis dan kemandirian belajar mahasiswa melalui pendekatan pembelajaran generatif pada matakuliah Struktur Aljabar di Program Studi Pendidikan Matematika STKIP PGRI Lubuklinggau. Variabel dalam kegiatan penelitian ini adalah hasil penerapan pendekatan pembelajaran generatif untuk meningkatkan kemampuan kritis dan kemandirian belajar pada matakuliah Struktur Aljabar di Program Studi Pendidikan Matematika STKIP PGRI Lubuklinggau. Subjek penelitian adalah mahasiswa semester V kelas A Program Studi Pendidikan Matematika STKIP PGRI Lubuklinggau tahun perkuliahan 2009/ 2010 yang berjumlah 23 orang. Metode penelitian yang dilakukan adalah menggunakan kuasi eksperimen yang terdiri dari satu kelas eksperimen yang menggunakan pendekatan pembelajaran generatif dan tidak ada kelas pengontrolnya. Hasil penelitian menunjukkan bahwa secara keseluruhan kemampuan berpikir kritis dan kemandirian belajar struktur aljabar mempunyai rerata 75,90 (dari skor minimum 70). Hal ini menunjukkan bahwa kemampuan berpikir kritis dan kemandirian belajar mahasiswa secara keseluruhan termasuk kategori tinggi. Sedangkan dari hasil analisis uji varians di dapat bahwa thitung $=3,954$ dan ttabel $(\mathrm{dk}=22$ á $=1 \%)=2,508$. Hal ini menunjukkan bahwa hasil belajar mahasiswa dengan melihat kualitas kemampuan berpikir kritis dan kemandirian belajar mahasiswa melalui pendekatan pembelajaran generatif pada matakuliah Struktur Aljabar di Program Studi Pendidikan Matematika STKIP PGRI Lubuklinggau telah mencapai nilai diatas 70.

Kata-kata kunci: berpikir kritis, pembelajaran generatif, struktur aljabar

\section{PENDAHULUAN}

Pendidikan nasional berfungsi mengembangkan kemampuan dan membentuk watak serta peradaban bangsa yang bermartabat dalam rangka mencerdaskan kehidupan bangsa. Pendidikan nasional bertujuan untuk berkembangnya potensi peserta didik agar menjadi manusia yang beriman dan bertaqwa kepada Tuhan Yang Maha Esa, berakhlak mulia, sehat, cakap, kritis, kreatif, mandiri, dan menjadi warga negara yang demokratis serta bertanggung jawab. Untuk mendukung tujuan pendidikan nasional tersebut, pembelajaran matematika di setiap jenjang 
pendidikan, mengacu pada dua tujuan pokok, yaitu tujuan formal dan tujuan material (Soedjadi, 1992). Tujuan formal pembelajaran matematika adalah tujuan yang barkaitan dengan penataan nalar dan pembentukan sikap peserta didik, sedangkan tujuan material pembelajaran matematika adalah tujuan yang berkaitan dengan penggunaan dan penerapan matematika, baik dalam matematika itu sendiri maupun bidang-bidang lainnya.

Melalui proses learning to know, mahasiswa memahami atau mengetahui secara bermakna: fakta, konsep, prinsip, hukum, teori, model dan idea matematika, hubungan antaridea dan alasan yang mendasarinya, serta menggunakan idea untuk menjelaskan dan memprediksi proses matematika. Melalui proses learning to do, mahasiswa didorong melaksanakan proses matematika (doing math) secara aktif untuk memacu peningkatan perkembangan intelektualnya. Melalui proses learning to be, mahasiswa menghargai atau mempunyai apresiasi terhadap nilai-nilai dan keindahan akan produk dan proses matematika yang ditunjukkan dengan sikap senang, bekerja keras, ulet, sabar, disiplin, jujur, serta mempunyai motif berprestasi yang tinggi, dan rasa percaya diri. Melalui proses learning to live together in peace and harmony, mahasiswa bersosialisasi dan berkomunikasi dalam matematika. Hal ini dilakukan melalui bekerja dan belajar bersama dalam kelompok kecil (cooperative learning), menghargai pendapat orang lain, menerima pendapat yang berbeda, belajar mengemukakan pendapat, dan atau bersedia sharing idea dengan orang lain dalam kegiatan matematika.

Dosen sebagai fasilitator, organisator, dan motivator pelaksana proses pembelajaran matematika, harus dapat memilih pendekatan pembelajaran yang tepat dan sesuai dengan karakteristik matematika sehingga memungkinkan tumbuhnya kemampuan berpikir kritis dan kemandirian belajar matematika pada mahasiswa. Sebagai fasilitator, dosen menyiapkan perangkat pembelajaran yang memungkinkan mahasiswa untuk menemukan sendiri konsep, prinsip, dan prosedur melalui serangkaian aktivitas pembelajaran. Sebagai organisator, dosen harus mampu mengelola jalannya proses pembelajaran termasuk cara-cara mengintervensi untuk mengarahkan mahasiswa dalam memahami konsep, prinsip, dan prosedur. Sebagai motivator, dosen memberikan motivasi kepada mahasiswa yang kurang aktif di dalam proses pembelajaran, dengan demikian proses pembelajaran akan menjadi aktif. Selain itu, yang penting juga adalah interaksi sosial memegang peranan penting dalam memahami pengetahuan dan perolehan keterampilan berpikir. Hasil temuan Doise, Mugny, dan Perret-Clermont (dalam Cesar, 2009) menunjukkan bahwa kemajuan siswa yang saling berinteraksi dalam menyelesaikan tugas lebih baik daripada siswa yang melakukan secara individu. Di samping itu, kemajuan pengembangan kognisi siswa lebih stabil dan hasil perolehan siswa lebih bertahan lama bila dibandingkan dengan siswa yang aktif secara individu.

Di dalam pembelajaran yang menekankan kemampuan konjektur dan interaksi sosial akan melatih mahasiswa untuk berpikir divergen dan konvergen. Menurut Gardner (2009), berpikir divergen adalah suatu kemampuan untuk menghasilkan banyak tanggapan, gagasan, pilihan atau alternatif jawaban atas suatu pertanyaan terbuka, tugas atau tantangan, serta berpikir konvergen adalah suatu kemampuan untuk menghasilkan tanggapan tunggal melalui petunjuk tertentu. Berpikir konvergen merupakan cara untuk mempertimbangkan atau mengevaluasi yang termasuk gagasan positif atau gagasan negatif sehingga seseorang dapat mengambil keputusan secara tepat dan efektif. Berpikir divergen dan konvergen merupakan salah satu syarat agar seseorang mempunyai kemampuan berpikir kritis dan kreatif.

Proses pembelajaran yang kurang menekankan pada aspek thinking akan membentuk mahasiswa cenderung mengoptimalkan dirinya dengan menerima saja apa yang diajarkan oleh dosen. Hal ini akan mengakibatkan fiksasi fungsional tentang makna kuliah yang keliru tertanam dalam diri mahasiswa yang pada gilirannya kemampuan bepikir kritis dan kemandirian belajar tidak terbentuk pada diri mahasiswa serta menumbuhkan sikap resistensi yang tinggi terhadap perubahan. Kemampuan berpikir kritis dan kemandirian belajar akan sulit terbentuk karena aspek-aspeknya lebih banyak diambil alih oleh dosen. Menurut mahasiswa, proses pembelajaran yang sekarang berjalan pada umumnya belum dipandang sebagai proses belajar mandiri karena pada umumnya mahasiswa masih mengharapkan dosen menyampaikan materi secara sistematis agar mahasiswa dapat mencatatnya dengan rapih.

Berdasarkan latar belakang yang telah diuraikan, maka rumusan masalah dalam penelitian ini adalah : Bagaimanakah kualitas kemampuan berpikir kritis dan kemandirian belajar mahasiswa melalui pendekatan pembelajaran generatif pada mata kuliah Struktur Aljabar di Program Studi Pendidikan Matematika STKIP PGRI Lubuklinggau? Oleh karena itu, tujuan penelitian ini adalah untuk menganalisis 
kualitas kemampuan berpikir kritis dan kemandirian belajar mahasiswa melalui pendekatan pembelajaran generatif pada mata kuliah Struktur Aljabar di Program Studi Pendidikan Matematika STKIP PGRI Lubuklinggau.

\section{KAJIAN PUSTAKA}

\section{Konsep dan Definisi}

Gagne (Ruseffendi, 1991) menyatakan bahwa konsep adalah ide abstrak yang memungkinkan untuk mengelompokkan benda-benda (objek-objek) ke dalam contoh dan noncontoh. Sedangkan Johnson dan Rising (dalam Soedjadi, 1993) menyatakan bahwa A concept is a mental abstraction of common properties of a set of experiences or phenomenas. The element of these sets may involves objects (set concepts), actions (operational concepts), comparisons (relational concepts), or organizations (structural concepts).

Menurut Soedjadi (1993), definisi dapat digolongkan ke dalam tiga kategori, yaitu (1) definisi analitik, (2) definisi ginetik, dan (3) definisi dalam bentuk rumus. Dalam definisi analitik, terdapat genus proksimum (genus yang terdekat) dan diferensiaspesifika contohnya persegi panjang adalah jajaran genjang yang mempunyai sudut siku-siku. Contoh ini terlihat bahwa persegi panjang tidak didefinisikan melalui segi empat, tetapi melalui "jajaran genjang" sebagai genus proksimumnya serta "mempunyai sudut siku-siku" merupakan diferensia-spesifikanya atau pembeda dari jajaran genjang pada umumnya. Dalam definisi ginetik, terdapat bagaimana cara terjadinya konsep itu contohnya, trapesium adalah segi empat yang terjadi jika sebuah segitiga dipotong oleh sebuah garis yang sejajar dengan salah satu sisinya. Definisi dalam bentuk rumus merupakan definisi yang langsung menggunakan rumus. Contohnya, definisi pengurangan pada bilangan real a dan $b$ ditulis sebagai $a-b=a+(-b)$

\section{Tinjauan Umum Mata Kuliah Struktur Aljabar}

Struktur Aljabar merupakan salah satu cabang matematika abstrak yang umumnya akan lebih sulit dibandingkan dengan cabang lain yang lebih konkret. Di dalam mata kuliah ini akan dibicarakan tentang himpunan dengan satu operasi dan dua operasi yang berupa Grup dan Ring (Gelanggang) yang merupakan suatu aljabar modern yang standar.

Mahasiswa diharapkan untuk mengambil terlebih dahulu mata kuliah Aljabar I, Aljabar II, dan Pengantar Dasar Matematika agar lebih mudah memahami mata kuliah ini. Struktur Aljabar merupakan materi tentang matematika abstrak, maka dalam hal ini tidak dilakukan perhitungan, tetapi belajar tentang konsep abstrak, fakta, serta prinsip yang saling berkaitan. Adapun materi yang akan dipelajari secara ringkas: a) operasi pada himpunan; b) monoid dan semigrup; c) dasar - dasar grup; d) grup siklik, grup permutasi, homomorfisma; e) grup faktor; f) ring (gelanggang); g) subring dan ideal; $h$ ) ring faktor dan homomorfisma; serta i) ring polinom.

\section{Berpikir Kritis}

Berpikir dapat diasumsikan sebagai proses kognisi dalam usaha untuk memperoleh pengetahuan. Berpikir merupakan kapabilitas atau kemampuan yang dapat dipelajari. Fisher (Launch Pad, 2001) mendeskripsikan bahwa paling sedikit tiga aspek penting keterampilan berpikir yaitu berpikir kritis, berpikir kreatif, dan problem solving. Ketiga aspek tersebut saling berkomplementer tetapi saling berhubungan. Problem solving perlu penemuan masalah dan pertanyaan-pertanyaan untuk menyelidiki (berpikir kreatif) dan mengevaluasi solusi yang diusulkan (berpikir kritis). Berpikir kritis perlu mengorganisasi keterampilan berpikir seseorang ke dalam suatu kombinasi sebagai alat kerja (berpikir kreatif). Pada akhirnya, berpikir kreatif perlu berpikir kritis. Problem solving mungkin berupa penyelidikan kreatif yaitu berhubungan dengan penyelidikan untuk menemukan solusi masalah-masalah open-ended, menggunakan berpikir divergen dalam menyelesaikan masalah, dan lain-lain.

Dalam usaha meningkatkan kemampuan berpikir kritis, maka harus memperhatikan fase-fase kemampuan berpikir kritis. Selanjutnya, akan diuraikan fase-fase kemampuan berpikir kritis menurut beberapa ahli.

Brookfield (1987) mengidentifikasi lima fase berpikir kritis, yaitu (1) Trigger event (cepat tanggap terhadap peristiwa), yaitu pengenalan suatu peristiwa tak terduga yang mengakibatkan terjadinya konflik kognisi internal; (2) Appraisal (penaksiran), yaitu menilai situasi dan mulai bekerja secara teliti, menghadapi peristiwa tak terduga dengan berbagai cara, mengklarifikasi dan mengidentifikasi perhatian orang lain dalam menghadapi situasi serupa; (3) Exporation (eksplorasi), yaitu mencari makna ke resolusi, atau cara dalam menjelaskan pertentangan untuk mengurangi konflik kognisi, mendorong seseorang untuk mencari maksud/arti, menyelidiki cara pikir dan bertindak; dan (4) Development alternative perspective (mengembangkan alternatif perspektif), yaitu mengembangkan cara pikir baru yang membantu seseorang menyesuaikan kepada peristiwa yang tidak 
diharapkan. Transisi ini melibatkan suatu usaha untuk mengurangi ketidaksesuaian dalam hidup seseorang; dan (5) Integration (integrasi), yaitu menegosiasikan perspektif baru untuk memfasilitasi integrasi perubahan hidup seseorang, melibatkan pengintegrasian konflik kognisi secara internal atau eksternal untuk mencapai suatu resolusi.

Garrison, Anderson, dan Archer (2001) membagi empat fase berpikir kritis, yaitu (1) Trigger event (cepat tanggap terhadap peristiwa), yaitu mengidentifikasi atau mengenali suatu isu, masalah, dilema dari pengalaman seseorang yang diucapkan instruktur, atau pelajar lain; (2) Exporation (eksplorasi), memikirkan ide personal dan sosial dalam rangka membuat persiapan keputusan; (3) Integration (integrasi), yaitu mengkonstruksi maksud atau arti dari gagasan dan mengintegrasikan informasi relevan yang telah ditetapkan pada tahap sebelumnya; dan (4) Resolution (mengulangi penyelesaian), yaitu mengusulkan solusi secara hipotesis, atau menerapkan solusi secara langsung kepada isu, dilema, atau masalah serta menguji gagasan dan hipotesis.

Berpikir kritis dalam belajar matematika merupakan suatu proses kognitif atau tindakan mental dalam usaha memperoleh pengetahuan matematika berdasarkan penalaran matematik. Penalaran matematik (Sumarmo, 2005) meliputi menarik kesimpulan logis; memberikan penjelasan dengan menggunakan model, fakta, sifat-sifat, dan hubungan; memperkirakan jawaban dan proses solusi; menggunakan pola dan hubungan untuk menganalisis situasi matematik; menarik analogi dan generalisasi; menyusun dan menguji konjektur; memberikan lawan contoh (counter example); mengikuti aturan inferensi; memeriksa validitas argumen; menyusun argumen yang valid; serta menyusun pembuktian langsung, pembuktian tak langsung, dan menggunakan induksi matematik.

Berpikir kritis matematik meliputi kemampuan untuk bereaksi terhadap masalah matematik dengan membedakan pendapat dan fakta, kesimpulan dan pertimbangan, argumentasi induktif dan deduktif, serta objektif dan subjektif. Selanjutnya kemampuan untuk membuat pertanyaan, mengkonstruksi dan mengenali struktur argumentasi, alasan-alasan yang mendukung argumentasi; mendefinisikan, menganalisis, dan memikirkan solusi permasalahan; menyederhanakan, mengorganisasi, mengklasifikasi, menghubungkan, dan menganalisis masalah matematik; mengintegrasikan informasi dan melihat hubungannya untuk menarik kesimpulan; selanjutnya memeriksa kelayakan kesimpulan, menerapkan pengetahuan dan pemahaman yang diperoleh ke permasalahan matematik yang baru.

Fisher menekankan pada indikator keterampilan berpikir kritis yang penting meliputi a) mengatakan kebenaran pertanyaan atau pernyataan; b) menganalisis pertanyaan atau pernyataan; c) berpikir logis; d) mengurutkan, misalnya secara temporal, secara logis, secara sebab-akibat; e) mengklasifikasi, misalnya gagasan-gagasan, objekobjek; f) memutuskan, misalnya apakah cukup bukti; g) memprediksi (termasuk membenarkan prediksi); h) berteori; serta i) memahami orang lain dan dirinya.

Berdasarkan uraian yang telah dikemukakan maka kemampuan berpikir kritis yang digunakan dalam penelitian ini adalah terdiri atas lima fase, yaitu memicu kejadian (trigger event), eksplorasi, menarik kesimpulan, klarifikasi, dan resolusi. Trigger event, yaitu kemampuan mengidentifikasi kelengkapan premis suatu pernyataan, konsep-konsep yang dibutuhkan dalam membuktikan suatu pernyataan. Eksplorasi, yaitu kemampuan mengkonstruksi makna atau arti dan menyelidiki ide matematik. Menarik kesimpulan yaitu kemampuan membuat dan memutuskan ide matematik secara induktif atau deduktif. Klarifikasi, yaitu kemampuan mengevaluasi dan menjelaskan, menentukan konteks ide matematik. Resolusi, yaitu kemampuan mengusulkan atau memperbaiki langkah-langkah bukti suatu pernyataan matematik.

\section{Pembelajaran Generatif}

Pembelajaran generatif adalah proses aktif dalam mengkonstruksi pengetahuan baru berdasarkan pengetahuan yang telah dimiliki sebelumnya. Pembelajaran generatif menitikberatkan pada caracara memperkuat dorongan internal manusia untuk memahami lingkungan dengan menggali dan mengorganisasi informasi, merasakan adanya masalah dan mengupayakan pemecahannya, serta mengembangkan bahasa untuk mengungkapkannya.

Menurut Osborne dan Wittrock (dalam Hulukati, 2005) bahwa esensi pembelajaran generatif adalah pikiran atau otak manusia bukanlah penerima informasi secara pasif tetapi aktif mengkonstruksi dan menafsirkan informasi dan selanjutnya menarik kesimpulan berdasarkan informasi itu. Pembelajaran generatif melibatkan aktivitas mental berpikir. Mental berpikir seseorang yang telah melakukan pembelajaran akan berkembang sejalan dengan proses belajarnya.

Dalam rangka mengembangkan struktur kognitif, menurut Piaget (Ruseffendi, 1991) terjadi dua proses, yaitu asimilasi dan akomodasi. Asimilasi 
adalah penyerapan informasi baru ke dalam pikiran, sedangkan akomodasi adalah menyusun kembali pikiran karena adanya informasi baru sehingga informasi itu punya tempat. Hal ini menunjukkan bahwa di dalam pembelajaran khususnya pembelajaran matematika diperlukan adanya keaktifan pebelajar untuk mengkonstruksi sendiri pengetahuan matematika dalam pikirannya agar skema yang dimilikinya menjadi berkembang. Misalkan seseorang ingin membuktikan suatu teorema, harus mengkonstruksi hubungan-hubungan definisi dan teoremateorema yang telah menjadi skema dalam pikirannya.

Menurut Osborne dan Wiltrock (dalan Sunal, 2000) bahwa model pembelajaran generatif mempunyai empat tahapan, yaitu (1) the preliminary step (tahap persiapan), (2) the focus step (tahap menfokuskan), (3) the challenge step (tahap tantangan), dan (4) the application step (tahap aplikasi).

\section{Hipotesis}

Hipotesis dalam penelitian ini adalah "Hasil belajar mahasiswa dengan melihat kualitas kemampuan berpikir kritis dan kemandirian belajar mahasiswa melalui pendekatan pembelajaran generatif pada mata kuliah Struktur Aljabar di Program Studi Pendidikan Matematika STKIP PGRI Lubuklinggau telah mencapai nilai di atas 70".

\section{METODOLOGI PENELITIAN}

\section{Variabel Penelitian}

Variabel dalam kegiatan penelitian ini adalah hasil penerapan pendekatan pembelajaran generatif untuk meningkatkan kemampuan kritis dan kemandirian belajar pada mata kuliah Struktur Aljabar di Program Studi Pendidikan Matematika STKIP PGRI Lubuklinggau.

\section{Subjek Penelitian}

Pada penelitian ini yang menjadi subjek adalah mahasiswa semester V kelas A Program Studi Pendidikan Matematika STKIP PGRI Lubuklinggau tahun perkuliahan 2009/2010 yang berjumlah 23 orang, terdiri dari 10 orang laki-laki dan 13 orang perempuan.

\section{Metode Penelitian}

Berdasarkan rumusan masalah, metode yang digunakan dalam penelitian ini menggunakan metode kuasi eksperimen, di mana mahasiswa semester $\mathrm{V}$ kelas A merupakan kelas eksperimen yang menggunakan pendekatan pembelajaran generatif dan tidak ada kelas pengontrolnya.

\section{Prosedur dan Waktu Penelitian}

Materi pembelajaran dituangkan dalam bentuk Lembar Kerja Mahasiswa (LKM) dengan merujuk pada karakteristik pembelajaran generatif. Pembelajaran dilakukan selama 32 kali pertemuan, pelaksanaannya 2 kali pertemuan setiap minggu selama $2 \times 50$ menit setiap pertemuan. Penelitian ini dilaksanakan dari tanggal 30 September 2009 sampai dengan 15 Januari 2010.

Tabel 1. Rincian Kegiatan Tatap Muka

\begin{tabular}{|c|c|c|}
\hline Pertemuan & Materi & Keterangan \\
\hline 1 & Silabus \& SAP & $\begin{array}{l}\text { Pendahuluan, } \\
\text { penjelasan silabus } \\
\text { \& SAP, pembagian } \\
\text { / penjelasan tugas }\end{array}$ \\
\hline 2,3 & $\begin{array}{l}\text { Operasi pada } \\
\text { himpunan } \\
\text { - Irisan dari } \\
\text { dua atau } \\
\text { lebih } \\
\text { himpunan } \\
\text { - Gabungan } \\
\text { dari dua } \\
\text { atau lebih } \\
\text { himpunan } \\
\text { - Komplemen } \\
\text { dari suatu } \\
\text { himpunan }\end{array}$ & $\begin{array}{l}\text { Pemberian materi / } \\
\text { tanya jawab / } \\
\text { diskusi }\end{array}$ \\
\hline 4,5 & $\begin{array}{l}\text { Operasi pada } \\
\text { himpunan } \\
\text { - } \quad \text { Relasi } \\
\text { - } \text { Pemetaan } \\
\text { bersifat } \\
\text { injektif, } \\
\text { surjektif } \\
\text { atau bijektif } \\
\text { - Operasi } \\
\text { biner pada } \\
\text { himpunan } \\
\text { - Sifat-sifat } \\
\text { dari operasi }\end{array}$ & $\begin{array}{l}\text { Pemberian materi / } \\
\text { tanya jawab / } \\
\text { diskusi }\end{array}$ \\
\hline 6,7 & $\begin{array}{l}\text { Monoid dan } \\
\text { semigrup } \\
\text { - Monoid } \\
\text { - Semigrup } \\
\text { Quiz }\end{array}$ & $\begin{array}{l}\text { Pemberian materi / } \\
\text { tanya jawab / } \\
\text { diskusi Quiz }\end{array}$ \\
\hline $8,9,10$ & $\begin{array}{l}\text { Dasar - dasar } \\
\text { grup } \\
\text { - Sifat-sifat } \\
\text { Grup } \\
\text { - Orde dari } \\
\text { Grup } \\
\text { - Subgrup }\end{array}$ & $\begin{array}{l}\text { Pemberian materi / } \\
\text { tanya jawab / } \\
\text { diskusi }\end{array}$ \\
\hline $11,12,13$ & $\begin{array}{l}\text { Grup siklik, } \\
\text { grup permutasi, } \\
\text { homomorfisma } \\
\text { grup } \\
\text { - Grup Siklik }\end{array}$ & $\begin{array}{l}\text { Pemberian materi / } \\
\text { tanya jawab / } \\
\text { diskusi }\end{array}$ \\
\hline
\end{tabular}




\section{Teknik Pengumpulan Data}

Teknik pengumpulan data yang digunakan dalam kegiatan ini adalah tes, yang diambil dari nilai tugas (kuis), ujian tengah semester (UTS), dan ujian akhir semester (UAS).

\section{Teknik Analisis Data}

Teknik analisis data yang digunakan dalam kegiatan ini adalah mengelompokkan skor nilai akhir mahasiswa berdasarkan kategori $\mathrm{A}=$ sangat baik, $\mathrm{B}=$ baik, $C=$ cukup, $\mathrm{D}=$ kurang, dan $\mathrm{E}=$ sangat kurang.

Menentukan skor rata-rata dan standar deviasi dari masing-masing kelompok, dengan rumus: (Furqon, 2002: 42 \& 61)

$$
\begin{gathered}
\bar{X}=\frac{\sum X_{i}}{n} \\
s=\sqrt{\frac{\sum\left(X_{i}-\bar{X}\right)^{2}}{n-1}}
\end{gathered}
$$

Keterangan:

$\overline{\mathrm{X}}$ : nilai rata-rata hasil belajar siswa

$\mathrm{X}_{\mathrm{i}}$ : nilai hasil siswa

n : jumlah siswa

S : simpangan baku / stándar deviasi

Selanjutkan melakukan uji varians dengan menghitung normalitas nilai akhir mahasiswa menggunakan uji Lilliefors, homogenitas nilai akhir mahasiswa terhadap jenis kelamin, dan uji-t dengan rumus:

$$
t=\frac{\bar{x}-\mu_{0}}{\frac{s}{\sqrt{n}}}
$$

\section{HASIL DAN PEMBAHASAN}

\section{Hasil Penelitian}

Deskripsi Pelaksanaan Kegiatan

Kegiatan ini dilaksanakan dari tanggal 30 September 2009 sampai dengan 15 Januari 2010 pada mahasiswa semester V kelas A di Program Studi Pendidikan Matematika STKIP PGRI Lubuklinggau tahun perkuliahan 2009/2010. Kegiatan ini dilakukan untuk mencapai kompetensi umum pada mata kuliah struktur aljabar, sehingga diharapkan mahasiswa Semester V kelas A di Program Studi Pendidikan Matematika STKIP PGRI Lubuklinggau dapat, sebagai berikut.

a) Menggunakan operasi pada himpunan untuk memecahkan masalah dan mengidentifikasi suatu himpunan terhadap suatu operasi biner.

b) Mengidentifikasi dan memahami konsep dari semigrup dan monoid.

c) Mengidentifikasi dan mengenal sifat-sifat dasar suatu grup.

d) Mengenal dan mengaplikasikan sifat-sifat grup siklik, grup permutasi, dan homomorfisma grup.

e) Mengenal dan mengaplikasikan sifat-sifat dari grup faktor.

f) Mengenal dan mengaplikasikan sifat-sifat suatu ring, integral domain, dan field.

g) Mengidentifikasi suatu ring merupakan subring dan ideal.

h) Mengenal dan mengaplikasikan sifat-sifat ring faktor dan homomorfisma ring.

i) Mengenal dan mengaplikasikan sifat-sifat ring polinom.

Dalam penelitian ini, pada setiap akhir pokok bahasan (PB) mahasiswa diberikan tugas di rumah untuk mengerjakan Lembar Kerja Mahasiswa (LKM) berupa tugas mandiri (mahasiswa mencari soal sendiri dan menyelesaikannya minimal 5 soal), yang akan dibahas pada seminar kelas setelah habis perkulihaan (pertemuan ke 14 dan 15). Latihan/quiz akan diberikan setelah habis dua pokok bahasan (PB)

Deskripsi Data

Evaluasi diadakan berupa tugas/kuis, ujian tengah semester (UTS) pada pertemuan ke-16, dan ujian akhir semester (UAS) pada pertemuan ke-32. Adapun hasil evaluasi dapat dilihat dalam tabel

\begin{tabular}{|c|c|c|c|c|c|c|}
\hline $\begin{array}{c}\text { No } \\
\text { Urut }\end{array}$ & $\begin{array}{c}\text { Jenis } \\
\text { Kelamin }\end{array}$ & Tugas & UTS & UAS & NA & Hasil \\
\hline 1 & Laki-laki & 85 & 75 & 98 & 88 & $\mathrm{~A}$ \\
\hline 2 & Laki-laki & 90 & 80 & 90 & 87 & $\mathrm{~A}$ \\
\hline 3 & Perempuan & 90 & 80 & 98 & 91 & $\mathrm{~A}$ \\
\hline 4 & Perempuan & 70 & 64 & 90 & 78 & $\mathrm{~B}$ \\
\hline 5 & Perempuan & 85 & 86 & 98 & 92 & $\mathrm{~A}$ \\
\hline 6 & Laki-laki & 80 & 88 & 98 & 91 & $\mathrm{~A}$ \\
\hline 7 & Perempuan & 85 & 75 & 90 & 86 & $\mathrm{~A}$ \\
\hline 8 & Perempuan & 70 & 55 & 90 & 76 & $\mathrm{~B}$ \\
\hline 9 & Laki-laki & 85 & 64 & 68 & 70 & B \\
\hline 10 & Laki-laki & 75 & 55 & 68 & 65 & $\mathrm{C}$ \\
\hline 11 & Laki-laki & 90 & 54 & 83 & 75 & B \\
\hline 12 & Perempuan & 75 & 56 & 60 & 62 & $\mathrm{C}$ \\
\hline 13 & Perempuan & 75 & 50 & 65 & 62 & $\mathrm{C}$ \\
\hline 14 & Perempuan & 90 & 81 & 60 & 72 & B \\
\hline 15 & Perempuan & 85 & 60 & 90 & 80 & B \\
\hline 16 & Perempuan & 90 & 70 & 80 & 79 & $\mathrm{~B}$ \\
\hline 17 & Laki-laki & 80 & 75 & 68 & 72 & B \\
\hline 18 & Laki-laki & 90 & 72 & 98 & 89 & $\mathrm{~A}$ \\
\hline 19 & Perempuan & 90 & 88 & 90 & 89 & A \\
\hline 20 & Laki-laki & 85 & 65 & 68 & 70 & B \\
\hline 21 & Laki-laki & 80 & 68 & 68 & 70 & $\mathrm{~B}$ \\
\hline 22 & Perempuan & 90 & 72 & 60 & 70 & $\mathrm{~B}$ \\
\hline 23 & & 75 & 80 & 80 & 79 & B \\
\hline \multicolumn{5}{|c|}{ JUMLAH } & 1793 & \\
\hline \multicolumn{5}{|c|}{ RATA-RATA } & $\begin{array}{c}77,9 \\
6\end{array}$ & B \\
\hline \multicolumn{5}{|c|}{ STANDAR DEVIASAI } & 9,65 & \\
\hline
\end{tabular}
berikut.

Tabel 2. Rincian Hasil Evaluasi 
Hasil nilai akhir mahasiswa menunjukkan bahwa rata-rata sebesar 77,96 (dikategorikan "baik") dengan standar deviasi 9,65.

Untuk menjawab hipotesis terlebih dahulu dicari normalitas dan homogenitas data nilai akhir mahasiswa. Dengan menggunakan uji Lilliefors didapat $\mathrm{L}_{\text {hitung }}=0,1228$ dan $\mathrm{L}_{\text {tabel }}=0,2155$ (dengan $\alpha=$ $1 \%$ ). Ini menunjukkan bahwa $\mathrm{L}_{\text {hitung }}<\mathrm{L}_{\text {tabel }}$ yang berarti bahwa data berdistribusi normal. Sedangkan untuk melihat kehomogenan data terhadap jenis kelamin digunakan uji Chi Kuadat, didapat $X^{2}{ }_{\text {hitung }}=0,0205$ dan $X_{\text {tabel }}^{2}=40,283$ (dengan $\mathrm{dk}=22, \alpha=1 \%$ ). Hasil ini menunjukkan bahwa $X^{2}{ }_{\text {hitung }}<X^{2}$ tabel yang berarti bahwa data homongen.

Selanjutnya dilakukan uji $t$, untuk melihat apakah hipotesis dapat diterima atau tidak. Dari perhitungan didapat bahwa $t_{\text {hitung }}=3,954$ dan $t_{\text {tabel(dk }}$ $=22$, á $=1 \%)=2,508$, yang berarti bahwa $t_{\text {hitung }}>t_{\text {tabel }}$ sehingga tolak $\mathrm{H}_{\mathrm{o}}$. Ini menunjukkan bahwa hasil belajar mahasiswa dengan melihat kualitas kemampuan berpikir kritis dan kemandirian belajar mahasiswa melalui pendekatan pembelajaran generatif pada mata kuliah Struktur Aljabar di Program Studi Pendidikan Matematika STKIP PGRI Lubuklinggau telah mencapai nilai di atas 70 .

\section{Pembahasan}

Tujuan utama penelitian ini adalah untuk menganalisis kualitas kemampuan berpikir kritis dan kemandirian belajar mahasiswa berdasarkan nilai akhir semester pada mata kuliah Struktur Aljabar di Program Studi Pendidikan Matematika STKIP PGRI Lubuklinggau. Penelitian ini merupakan kuasi eksperimen, di mana tidak ada kelas kontrol dalam penelitian ini. Hasil nilai akhir mahasiswa berdasarkan kategori, sebagai berikut.

Tabel 3. Rekapitulasi Nilai Mahasiswa

\begin{tabular}{|l|l|l|l|l|l|}
\hline Nilai & Kategori & $\begin{array}{c}\text { Jumlah } \\
\text { NA }\end{array}$ & $\begin{array}{c}\text { Jumlah } \\
\text { Mahasiswa }\end{array}$ & $\begin{array}{c}\text { Rata- } \\
\text { rata }\end{array}$ & $\begin{array}{l}\text { Standar } \\
\text { Deviasi }\end{array}$ \\
\hline A & $\begin{array}{l}\text { Sangat } \\
\text { baik }\end{array}$ & 712.00 & 8.00 & 89.00 & 2.36 \\
\hline B & Baik & 891.00 & 12.00 & 74.25 & 0.78 \\
\hline C & Cukup & 189.00 & 3.00 & 63.00 & 3.18 \\
\hline D & Kurang & - & - & - & - \\
\hline E & $\begin{array}{l}\text { Sangat } \\
\text { kurang }\end{array}$ & - & - & - & - \\
\hline
\end{tabular}

Deskripsi Kemampuan Berpikir Kritis dan Kemandirian Belajar Matematika merupakan gambaran kualitas kemampuan berpikir kritis dan kemandirian belajar matematika berdasarkan rerata, standar deviasi, dan jumlah mahasiswa adalah baik secara keseluruhan maupun berdasarkan jenis pendekatan pembelajaran generatif pada mata kuliah struktur aljabar. Ini ditunjukkan dengan 12 orang atau $52,17 \%$ mahasiswa termasuk dalam kategori baik dan 8 orang atau $34,78 \%$ termasuk dalam kategori sangat baik.

Sehingga dapat diuraikan deskripsi kemampuan berpikir kritis dan kemandirian belajar mahasiswa, sebagai berikut.

a. Secara keseluruhan, kemampuan berpikir kritis dan kemandirian belajar struktur aljabar mempunyai rerata 77,96 (dari skor minimum 70 ). Hal ini menunjukkan bahwa kemampuan berpikir kritis dan kemandirian belajar mahasiswa secara keseluruhan dengan pendekatan pembelajaran generatif termasuk kategori tinggi.

b. Dengan menggunakan uji varians didapat bahwa $t_{\text {hitung }}=3,954$ dan $t_{\text {tabel }(\mathrm{dk}=22, a ́=1 \%)}=2,508$, yang berarti bahwa $t_{\text {hitung }}>t_{\text {tabel }}$. Hal ini menunjukkan bahwa hasil belajar mahasiswa dengan melihat kualitas kemampuan berpikir kritis dan kemandirian belajar mahasiswa melalui pendekatan pembelajaran generatif pada mata kuliah Struktur Aljabar di Program Studi Pendidikan Matematika STKIP PGRI Lubuklinggau telah mencapai nilai di atas 70 .

\section{PENUTUP}

\section{Kesimpulan}

Berdasarkan hasil penelitian dan pembahasan hasil penelitian yang telah dikemukakan secara keseluruhan, kemampuan berpikir kritis dan kemandirian belajar mahasiswa dengan pendekatan pembelajaran generatif termasuk kategori tinggi. Ini dapat dilihat dari rerata hasil belajar mahasiswa yang dengan pendekatan pembelajaran generatif sebesar 77,96 . Hasil ini diperkuat dengan uji varians yang menunjukkan $\mathrm{t}_{\text {hitung }}=3,954$ dan $\mathrm{t}_{\text {tabel }(\mathrm{dk}=22, \text { a }=1 \%)}=2,508$, yang berarti bahwa $t_{\text {hitung }}>t_{\text {tabel. }}$ Dengan demikian, kualitas kemampuan berpikir kritis dan kemandirian belajar mahasiswa melalui pendekatan pembelajaran generatif pada mata kuliah Struktur Aljabar di Program Studi Pendidikan Matematika STKIP PGRI Lubuklinggau telah mencapai nilai di atas 70 .

\section{Saran}

Berdasarkan hasil penelitian dan pembahasan hasil penelitian yang telah dikemukakan, peneliti memberikan saran sebagai berikut, pertama, untuk dosen yang menerapkan pendekatan pembelajaran generatif perlu mengelola kelas dengan baik agar 
mahasiswa tetap terlibat secara aktif dalam proses pembelajaran karena keberhasilan suatu pembelajaran tidak hanya ditentukan oleh hasil belajar tetapi juga oleh keaktifan mahasiswa dalam proses pembelajaran.

Kedua, agar mahasiswa yang mempunyai kemampuan berpikir kritis dan kemandirian belajar harus juga berpikir kreatif, karena seorang mahasiswa yang mempunyai kemampuan berpikir kritis belum tentu mempunyai kemampuan berpikir kreatif.

\section{DAFTAR PUSTAKA}

Brookfield, S. D. (1987). Developing critical thinkers. San Fransisco: Jossey-Bass

Cesar, M. (2009). Social interactions and mathematics learning. Diakses pada tanggal 14 Juli 2009 dari http://www.nottingham.ac.uk/csme/meas/ papers/cesar.html

Furqon. (2002). Statistika terapan untuk penelitian. Bandung: Alfabeta.

Gardner, K.A. (2009). The dynamic balance: Divergence and convergence. Diakses pada tanggal 14 Juli 2009 dari http://www.buffalostate.edu/orgs/ cbir/readingroom/Gardner-99.html

Garrison. D. R., Anderson, T. \& Archer, W. (2009). Critical thinking and computer conferencing: A model and tool to assess cognitive presence. Diakses pada tanggal 14 Juli 2009 dari http:// communitiesofinquiry.com/documents/ CogPres_Final.pdf.
Hulukati, E. (2005). Mengembangkan kemampuan komunikasi dan pemecahan masalah matematika siswa smp melalui model pembelajaran generatif. Bandung: PPS UPI.

Pad, L. (2001). Thinking skill. Westminster Institute of Education. Oxford Brookes University.

Ruseffendi, H.E.T. (1991). Pengantar kepada membantu guru mengembangkan kompetensinya dalam pengajaran matematika. Bandung: Tarsito.

Soedjadi, R. (1992). Pokok-pokok pikiran tentang orientasi masa depan matematika sekolah di Indonesia. Media Pendidikan Matematika. Surabaya: PPs IKIP Surabaya.

Soedjadi, R. (1993). Simplifikasi beberapa konsep dalam matematika. Surabaya: PPS IKIPSurabaya.

Sumarmo, U, (2005). Pengembangan berpikir matematik tingkat tinggi siswa SLTP dan SMU serta mahasiswa strata satu (S1) melalui berbagai pendekatan pembelajaran. Laporan Penelitian Hibah Pascasarjana Tahun Ketiga. UPI Bandung.

Sunal, D,W. (2009). The Learning cycle: a comparison of models of strategies for conceptual reconstruction: a review of the literature. Diakses pada tanggal 14 Juli 2009 dari http://www.warwick.ac.uk/.

\section{KETERANGAN PENULIS}

Fadli lahir pada tanggal 11 September 1976. Saat ini aktif menjabat sebagai dosen jurusan Kopertis Wil II DPK pada STKIP PGRI Lubuklinggau. 